\title{
Perception Of Sustainability Of A Tourism Destination: Analysis From Tourist Expectations
}

Juan Ignacio Pulido-Fernández, University Of Jaén, Spain

Yaiza López-Sánchez, University Of Jaén, Spain

\begin{abstract}
This paper demonstrates that different assessments of the tourism attributes of a destination exist according to whether the perception of those tourists visiting that destination is that it is sustainable or whether, on the contrary, they perceive that it shows problems of unsustainability. Consequently, for a destination to be able to advance in terms of sustainability, it is not enough just to implement supply policies, but it is also necessary that "its" tourists are involved in this process as well; that is, demand policies must be developed that ensure a greater awareness and responsibility of tourists in the destinations they visit.
\end{abstract}

Keywords: Sustainability; Sustainable Tourism; Destination Image; Expectations; Perceptions; Tourist Behavior

\section{INTRODUCTION}

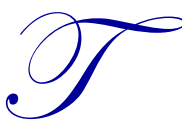

hough relatively recent, scientific literature on destination image (DI) has been abundant in recent years, which proves the growing importance of image in the development of a tourism destination. An appropriate image allows making the potential clients aware of the differential aspects of the place, which generates competitive advantages, as well as trust in the destination, favouring tourists' attraction and loyalty.

Moreover, image has a strong influence on the behaviour of tourism demand, not only before travelling, but also during the stay, and even in the future. It should be noted that, in general, tourists have a limited knowledge about the destinations they have yet to visit, so a strong, positive, distinctive image that is recognizable in the home markets of these potential tourists lends significant support to the competitive positioning of the destination.

In recent years, there has been much discussion about how unequivocal the change towards sustainability in tourism behaviour is (in line with what most studies show regarding general consumer trends). Some studies show that this change is actually taking place and that tourists tend to an increasingly responsible behaviour, while others, on the contrary, show that tourists only have a superficial awareness on environmental issues, as they state they are concerned, but, in practice, they are reluctant to take personal corrective measures.

What seems increasingly clear is that there is a demand segment which values sustainability and takes it into account when choosing a destination to enjoy their holidays. In other words, there is a market for those products and/or destinations that make a serious commitment to sustainability as a distinguishing feature and are able to convey an image of being "sustainable", which must later coincide, of course, with the perceptions that customers get when visiting the destination.

It is therefore essential to know how tourists understand sustainability and whether they are able to identify values related to sustainability in a destination. The key question is determining whether, based on their consideration of the sustainability of a destination, tourists show a different assessment of the attributes of the image that it conveys (both in their expectations and their perceptions). Put another way, do tourists really know what sustainability implies for a destination? What do they expect from a destination, depending on what they consider sustainable or not? Are tourists who value sustainability as a basic attribute of the destination more demanding? 
In this context, the hypothesis suggested in the present analysis is that there is a different assessment of the tourism attributes of the destination analysed (the Western Costa del Sol) depending on whether the perception of tourists who visit it is that they are visiting a sustainable destination or, on the contrary, that problems of unsustainability exist there.

\section{THEORETICAL FRAMEWORK}

Tourism marketing should not only be regarded as a tool for attracting more visitors, as it has been the case for most destinations. Instead, marketing should be used as a strategic mechanism in coordination with planning and management rather than a sales tool, to achieve strategic objectives that ensure the sustainability of the destination.

In this context, image occupies an increasingly prominent position, as it conditions the results of any marketing strategy. In fact, image is one of the attributes of the destination that has been most extensively studied by research. Thus, the mere conceptualisation of DI has been one of the main challenges for researchers (Chon, 1990; Echtner \& Ritchie, 1991; Henderson, 2007; Hunt, 1975; Kim \& Richardson, 2003; among others).

DI has been extensively studied over the years, so many and different conceptual approaches exist (Crompton, 1979; Echtner \& Ritchie, 1991; Kim \& Richardson, 2003; Kotler, et al., 1993; Morgan et al., 2012; Murphy et al, 2007; among others). In summary, DI can be considered as a general impression or as the set of tourists' individual impressions of a particular tourism destination or, more specifically, the set of expectations and perceptions that a potential tourist has about a destination.

It has been widely accepted in the literature that DI influences tourists' behaviour (Bigné et al., 2001; Chen \& Tsai, 2007; Cooper et al., 1993; Fakeye \& Crompton, 1991). Moreover, DI directly influences tourists' intention to revisit and recommend a destination to others (Alcaniz et al., 2005; Bigné et al., 2001; Qu et al., 2011).

Before their visit, tourists develop an image about destinations as well as a set of expectations based on knowledge (previous experience, word of mouth, press reports, advertising, and common beliefs), feelings and overall perception of a particular destination (Baloglu \& Brinberg, 1997; Chon, 1992; Crompton, 1979; Fakeye \& Crompton, 1991).

In order to gain a competitive advantage, a destination must create and convey a positive image (San Martín \& Rodríguez, 2008). In fact, destinations compete mainly through the image perceived by potential tourists, given that their preliminary idea of the destination determines their decision whether or not to visit it.

Every tourism destination tries to satisfy the desires and expectations of the tourists it hosts and, at the same time, to generate expectations in potential tourists' minds for them to opt for this destination. It is undeniable that tourists have evolved and, therefore, so too have their expectations about their experience at the destination, since, as Anuar et al. (2012: 108) state, "the changes of tourists' tastes are a factor due to the changes of tourists' character, attitude and lifestyle towards a tourism destination".

Regarding sustainability, numerous studies on tourism consumer behaviour indicate that there is a growing awareness of the environmental, social and cultural impacts that can be generated by tourism activity (Adlwarth, 2010; Dodds et al., 2010; Hedlund, 2011; Kucukusta et al., 2013). Furthermore, in recent years, a significant number of studies have been published that attempt to measure the potential of demand segments with motivations linked to sustainability (Deloitte 2008; Lonely Planet, 2007; Rheem 2009; Wehrli et al., 2011).

As noted by Sanchez \& Pulido (2012: 250), “one of a destination's main strategic tools to ensure improvement in its competitive positioning is its capacity to communicate its attractions and, above all, to adapt them to the needs, tastes and expectations of its potential clients". Therefore, if a country wants to differentiate itself in the market as a destination that carries out practices and offer tourism products of a "sustainable" nature - in short, as a "sustainable" destination - the image that it conveys will be crucial to encourage more visitors to appreciate and value these issues. 
Thus, the question is, "what are the expectations of a tourist who values the sustainability of a destination?" Identifying these expectations is essential for the development of more effective segmentation strategies and for the implementation of promotional activities aimed at demand segments that value sustainability as a key factor in their destination choice.

Moreover, in the analysis of image, the concept of perception has a special interest - image includes the personal perception of the multiple components of the tourism destination. That is, tourists cannot really confirm their expectations until they reach that place and live the experience (Gopalan \& Narayan, 2010). In fact, as argued by Gómez et al. (2012), the image perceived by visitors may be different from the expectations prior to the visit, as a result of their lived experiences.

The expectations of tourists before visiting a destination and what is actually enjoyed once the trip has ended are two key aspects for the consolidation of a destination brand, its image and tourists' loyalty for future visits (Folgado et al., 2012).

It should be noted that this article does not intend to analyse all the possible dimensions of the DI (as seen in Sánchez \& Pulido, 2012), but to give an approximate picture of it from a set of initial attributes that allow the assessment of the destination as a whole and, especially, of issues related to sustainability.

Therefore, in this article, the analysis of DI, focussing on the Western Costa del Sol, is based on the comparison between individuals' initial expectations and their subsequent perception, after the tourism experience, distinguishing between two initial groups of tourists: i) those who think that the destination is sustainable and ii) those who consider that the destination is unsustainable. Thus, the analysis reveals whether or not the experience lived in the destination exceeds the expectations that tourists had when they opted for it, making a distinction between those who think they are in a sustainable destination and those who, on the contrary, consider it unsustainable. In fact, disconfirmation of expectations is a very common method in the study of satisfaction in many sectors - health, hotel, automotive, etc. (San Martin, 2005) - in which prior beliefs are understood as the standard for comparison, after the visit, in the disconfirmation judgement (Szymanski \& Henard, 2001).

\section{CASE AND DATA COLLECTION}

This analysis has been conducted in the Western Costa del Sol (Andalusia, Spain), which stands out as a typical mature and obsolete sun-and-sand tourism destination (Agarwal \& Shaw, 2007; Bramwell, 2004; Navarro, 2005, 2006, 2010; Pulido \& López, 2013; Vera \& Rodríguez, 2010) in need of renewal of its tourism development patterns.

Since tourism began to develop in Malaga in the mid-fifties, this activity has become a powerful driving force for the transformation and modernisation of its entire coastline. However, this process has generated a strong pressure on the land which, in turn, has radically changed the character of the coast (Navarro, 2005). The massive occupation of spaces has caused a serious impact on the landscape that has resulted in a new reality, more complex from a territorial and sustainable point of view.

During the last fifty years, and especially in the last decade, the processes of urbanisation along the coast of Malaga have been developed at a rapid pace, which has not only exhausted much of the areas of higher tourism quality, especially the strip of land closest to the sea, but also conditioned significantly the future of tourism activity. Specifically, as stated by Galacho (2009: 38), " $95 \%$ of this coastline, from Torremolinos to Manilva, was already developed in the early eighties."

This has led to a chaotic tourism development model that requires the implementation of new tourism policies supported by a planning action based on sustainability criteria. Nonetheless, the general feeling that urban development has already saturated all the territory, or that there is no alternative, does not reflect the reality of the situation since there is still considerable leeway to redefine a more desirable future for the Western Costa del Sol. 
The aim is precisely to take advantage of this margin to implement the Plan Qualifica ${ }^{1}$, whose ultimate goal is to achieve a profound change in the 'Costa del Sol' traditional tourism model, changing from a development model based on growth to a new one based on quality, innovation and sustainability.

It is, therefore, an appropriate tourism destination to carry out this research, the aim of which is twofold: 1) to analyse the role of tourists in the management of a tourism destination that seeks to focus on sustainability and 2) to determine whether a sustainable tourist, to whom sustainability policies can be oriented, actually exists in this type of destination or whether, on the contrary, it is necessary to change the demand, as Miller et al. (2010) stated. To this end, a survey was conducted in the municipalities that are part of the tourism destination under study (see Table 1). Given the impossibility of identifying the target population (tourists visiting the Western Costa del Sol) due to the lack of adequate statistical information, a simple random sampling was conducted, carrying out 818 valid surveys with domestic and foreign tourists who stay overnight at any of the cities that make up this destination.

Table 1: Survey Data Sheet

\begin{tabular}{|l|l|}
\hline Universe & Tourists (domestic and foreign) staying overnight at one of the cities of the destination \\
\hline Scope & $\begin{array}{l}\text { Torremolinos, Benalmadena, Fuengirola, Mijas, Marbella, Estepona, Casares and Manilva ( Plan } \\
\text { Qualifica municipalities) }\end{array}$ \\
\hline Type Of Survey & Structured questionnaire conducted by personal interview \\
\hline Sample Size & 818 valid surveys \\
\hline Sampling Error & $\pm 3,4 \%$ \\
\hline Confidence Level & $95 \%(\mathrm{p}=\mathrm{q}=0,50)$ \\
\hline Fieldwork Period & July and August 2011 \\
\hline
\end{tabular}

Source: Authors' own elaboration

Regarding the structure of the survey, it should be noted that only a few specific issues have been analysed in this study since the full survey is very long and distinguishes four main sections: 1) characterization of tourism demand, 2) characterization of tourism demand in terms sustainability, 3) tourists' perception about destination sustainability, and 4) tourists' willingness to pay for a more sustainable destination. Specifically, the questions used in this work belong to the third section, complemented by some questions from the second section that make it possible to complete the information.

\section{RESULTS AND DISCUSSION}

The data from the survey conducted in the Western Costa del Sol show that seven out of 10 tourists visiting this destination $(70.17 \%)$ consider it sustainable, compared to three out of $10(29.83 \%)$ who consider that they are visiting an unsustainable destination. To understand these data, the different interpretations of the term sustainability (see Table 2) must be previously analysed. This information is essential to determine whether respondents actually understand the real value and meaning of a destination being considered and promoted as sustainable. Therefore, some of the options include actions directly related to the basic pillars of sustainability (social equity, economic efficiency and environmental conservation).

Table 2: Interpretation Of Sustainability (\%)

\begin{tabular}{|c|c|c|}
\hline Being A Sustainable Destination Means ... & Yes & No \\
\hline respecting and caring for the environment & 94.50 & 5.50 \\
\hline local businesses benefiting from tourism & 71.39 & 28.61 \\
\hline allowing an increase of the number of tourists per year & 51.71 & 48.29 \\
\hline tourism improving the living conditions of the local population & 61.74 & 38.26 \\
\hline the destination being able to continue to grow & 51.96 & 48.04 \\
\hline destination's residents being able to decide about tourism growth & 45.11 & 54.89 \\
\hline the destination being able to satisfy all tourists' needs & 60.64 & 39.36 \\
\hline
\end{tabular}

Source: Authors' own elaboration

\footnotetext{
${ }^{1}$ Included in the Requalification Program for Mature Tourism Destinations (Spanish Tourism Plan Horizon 2020).
} 
As noted, there is a widespread belief that sustainability is directly linked to environmental conservation (94.50\%), which proves the link, almost exclusively, between sustainability and environmental issues, due to the outdated idea that the sustainability of a destination can only be achieved through actions in favour of the conservation and maintenance of the environment, the conservation of the biodiversity, the rational use of natural resources, etc.

Regarding the social and economic benefits that sustainable management implies for the territory, $71.39 \%$ of the respondents relate sustainability of the destination to the generation of profit by local businesses and $61.74 \%$ of them defend the idea that sustainable tourism improves the standard of living of the local population. Nevertheless, the percentage falls considerably $(45.11 \%)$ when it is suggested that sustainability is linked to the fact that residents themselves are those who decide about the tourism growth of the destination.

This is significant since it must be taken into account that the destination residents are a crucial part of the destination itself. Tourists interact and coexist with residents during their stay and, even though they may be the direct beneficiaries of this economic activity, they also suffer the costs and impacts of tourism mismanagement. Accordingly, it makes sense for local people to participate in making decisions that have a direct impact on their quality of life, but tourists do not give so much importance to this aspect as to environmental and economic issues.

The options included in this study demonstrate a type of tourist who knows the implications of sustainable tourism development in some of its dimensions, the most widely accepted of which being its environmental dimension $(94.50 \%)$. However, $60.64 \%$ of the respondents consider that the destination must meet all tourists needs, regardless of whether they respect (at all times or not) the local resources, character and values, putting the satisfaction of his own desires and needs before the respect and care for the host community.

Finally, more than half of the respondents $(51.71 \%)$ considered that sustainable tourism is that which allows an increase in the number of tourists each year or at least allows the destination to continue growing $(51.96 \%)$. However, it is well known that sustainable tourism measures its efficiency in terms of quality and not exclusively in terms of quantity. The fact that a tourism destination continues to grow does not implicitly mean that the territory will achieve a greater long-term development. On the contrary, the growing environmental and social costs may soon outweigh the economic benefits. Some authors (Sahli \& Nowak, 2007) even argue that tourism can cause economic costs that may become so high as to generate the impoverishment of the resident population.

Despite the clear limitations of some of the respondents with regard to the concept of sustainability - or, precisely, as a result of that, as previously noted $-70.17 \%$ of respondents declare that the Western Costa del Sol is a sustainable tourism destination, compared to $29.83 \%$ of them who deny this.

Moreover, advancing towards the characterisation of tourism demand in terms of sustainability, another issue raised was whether tourists considered it important to work for the sustainability of tourism destinations, to which $90.3 \%$ answered yes. Those tourists who responded affirmatively assessed ( 1 =unimportant; $7=$ very important) some of the reasons why a destination must be sustainable (see Table 3).

Table 3: Reasons Why Destinations Must Be Sustainable - According To Tourists (\%)

\begin{tabular}{|c|c|c|c|c|c|c|c|}
\hline & 1 & 2 & 3 & 4 & 5 & 6 & 7 \\
\hline It is important for those destinations to continue growing and creating jobs & 1.4 & 1.2 & 3.8 & 7.6 & 19.8 & 18.1 & 48.2 \\
\hline For my children to be able to continue going on holidays to those destinations & 3.4 & 1.9 & 5.5 & 14.6 & 27.3 & 17.2 & 30.0 \\
\hline $\begin{array}{l}\text { The citizens who were born and/or live in those destinations have the right to } \\
\text { enjoy a good quality of life }\end{array}$ & 1.2 & 0.9 & 3.1 & 6.6 & 16.5 & 24.2 & 47.4 \\
\hline Most traditional tourism destinations are seriously threatened & 5.4 & 4.2 & 8.7 & 13.7 & 26.5 & 20.3 & 21.2 \\
\hline
\end{tabular}

Source: Authors' own elaboration

Tourists who believe that destinations should work towards sustainability justify their answer, mainly on two issues: 1) for the citizens who were born and/or live in those destinations to enjoy a good quality of life (71.6\% assess this between important and very important) and 2) to continue growing and creating jobs in those destinations (66.3\% assess it between important and very important). It should be added that some tourists (18\%) proposed other reasons linked to environmental issues (protecting the landscape, nature, the coast, etc.). 
In contrast, regarding the $9.7 \%$ of tourists who do not consider that it is important to work towards the sustainability of tourism destinations, the main reasons are:

- They do not believe in the "sustainability" of destinations, as it appears to be simply a marketing concept $(44.3 \%)$.

- $\quad$ They believe that the unsustainable situation of tourism destinations cannot be reversed; it cannot be controlled (31.7\%).

The survey also reveals that $80.8 \%$ do not consider the fact that it was a mass destination to be important when choosing their holidays. Moreover, $60.1 \%$ are not concerned with the fact that tourism may adversely affect the residents of their holiday destination, which leads to tourists being rejected by the local population. These questions help to understand that $70.17 \%$ of the respondents assess the destination as being sustainable; however, their idea of sustainability differs much from the scientific and academically accepted.

After evaluating tourists' profiles on issues related to sustainability, an assessment of DI has been carried out from tourists' expectations (destination image prior to the visit) and perceptions (destination image after the visit), by doing a comparative analysis between those who consider the destination to be sustainable and those who do not believe so. In order to identify differences between the two groups, they were all asked to rate (on a scale of 1 to 7 points where 1 means not at all satisfied and 7 means very satisfied) what they expected to find at the destination (expectations) and what they have actually found in it (perceptions). The comparison between expectations and perceptions can give very clear guidance on the specific attributes of a destination determining a positive (sustainability) or negative (unsustainability) opinion about the destination analysed.

Table 4 shows a hierarchy of the expectations stated by both groups. In all cases, the mean value of the eleven attributes analysed in this destination has been calculated and they have been ordered from highest to lowest in numerical value.

The first clear conclusion that emerges from the data included in Table 4 is that what a tourist (who regards this destination as sustainable) expects to find markedly exceeds what a tourist (who believes that the Western Costa del Sol is not a sustainable destination) expects to find. In fact, mean values are higher in the first group than in the second group in all attributes analysed.

Table 4: Hierarchy Of Expectations In Relation To The Attributes Of The Destination Western Costa Del Sol

\begin{tabular}{|c|c|}
\hline $\begin{array}{c}\text { Destination Regarded As SUSTAINABLE } \\
\text { (Subsample Size: } n=574)\end{array}$ & $\begin{array}{c}\text { Destination Regarded As UNSUSTAINABLE } \\
\text { (Subsample Size: } n=244 \text { ) }\end{array}$ \\
\hline 1. Public safety $(5.42)$ & 1. Good value for money $(4.81)$ \\
\hline 2. Customer service and care (5.34) & 2. Availability of local products and services (4.75) \\
\hline 3. Good value for money (5.29) & 3. Customer service and care (4.73) \\
\hline 4. Availability of local products and services (5.17) & 4. Quality of the urban environment (cleanliness, traffic, \\
\hline 5. Good relationship and attitude of residents towards & noise, etc.) $(4.71)$ \\
\hline tourism $(5.12)$ & 5. Availability of an urban transport system (4.66) \\
\hline 6. Quality of the urban environment (cleanliness, traffic, & 6. Public safety (4.66) \\
\hline noise, etc.) (5.04) & 7. Quality of the natural environment (4.57) \\
\hline 7. Quality of the natural environment (5.01) & 8. Accessibility (communication network, access, ect.) (4.55) \\
\hline 8. Accessibility (communication network, acces, ect.) (5.01) & 9. Good relationship and attitude of residents towards tourism \\
\hline 9. Availability of an urban transport system (4.94) & $(4.49)$ \\
\hline 10. It is not an overcrowded destination (4.48) & 10. It is not an overcrowded destination (3.97) \\
\hline 11. Availability of a cultural programme (4.30) & 11. Availability of a cultural programme (3.95) \\
\hline
\end{tabular}

Source: Authors' own elaboration

Thus, a tourist who assesses the Western Costa del Sol as a sustainable destination expects to find a highquality offer during his stay in that area. If the perception of this tourist meets his expectations about a specific tourism service, that service will have little influence on the decision made by this tourist regarding the sustainability of the destination. However, if the perception of that tourist (what he has actually found in the destination) is better - even than the expectation that he previously created in relation to a specific tourism service - 
that service will contribute to the fact that the tourist opts for a positive assessment regarding the tourism sustainability of the destination. Consequently, it is necessary to compare perceptions and expectations in this first group of tourists (those who consider it a sustainable destination) in order to identify those aspects that are influencing tourists to consider the Western Costa del Sol as a sustainable tourism destination.

Similarly, among the group of tourists who believe that the Western Costa del Sol is unsustainable, a comparison between the expectations and perceptions regarding different attributes of the destination will be required, as the view that the destination is unsustainable will probably be based on those tourism attributes in which expectations exceed perceptions, since a source of tourists' disappointment or frustration will be found in them.

Table 5 presents the perceptions of both groups of tourists regarding different attributes of the destination Western Costa del Sol, ranked from higher to lower mean score, understanding that the lower in the mean score, the greater the degree of dissatisfaction stated by tourists.

Table 5: Hierarchy Of Perceptions In Relation To The Attributes Of The Destination Western Costa Del Sol

\begin{tabular}{|c|c|}
\hline $\begin{array}{l}\text { Destination Regarded As SUSTAINABLE } \\
\text { (Subsample Size: } n=574 \text { ) }\end{array}$ & $\begin{array}{c}\text { Destination Regarded As UNSUSTAINABLE } \\
\text { (Subsample Size: } n=244)\end{array}$ \\
\hline 1. Public safety (5.62) & 1. Customer service and care received (4.78) \\
\hline Customer service and care received (5.53) & 2. Good relationship and attitude of residents towards tourism \\
\hline Good relationship and attitude of residents towards & $(4.77)$ \\
\hline tourism $(5.34)$ & 3. Public safety (4.73) \\
\hline 4. Availability of local products and services (5.28) & 4. Quality of the urban environment (cleanliness, traffic, \\
\hline 5. Quality of the urban environment (cleanliness, traffic, & noise, etc.) $(4.73)$ \\
\hline noise, etc.) (5.19) & 5. Accessibility (communication network, access, ect.) (4.64) \\
\hline 6. Accessibility (communication network, access, ect.) & 6. Availability of local products and services (4.63) \\
\hline$(5.07)$ & 7. Availability of an urban transport system (4.62) \\
\hline 7. Quality of the natural environment (4.99) & 8. Quality of the natural environment (4.02) \\
\hline 8. Availability of an urban transport system (4.90) & 9. Good value for money $(4.00)$ \\
\hline Good value for money (4.86) & 10. It is not an overcrowded destination (3.86) \\
\hline 10. It is not an overcrowded destination (4.44) & 11. Availability of a cultural programme (3.84) \\
\hline 11. Availability of a cultural programme (4.26) & \\
\hline
\end{tabular}
Source: Authors' own elaboration

Likewise, Table 6 shows the results obtained by comparing the sample mean values of expectations and perceptions in relation to the eleven attributes analysed in the Western Costa del Sol for the group of tourists who consider this destination as sustainable. To do this, a student's t-test of the difference of means (considering equal variances or unequal variances, as appropriate) has been used. Statistically significant differences have been set at $5 \%$ level.

Finally, Table 7 is presented, which is identical to Table 6, but which now considers the group of tourists describing the Western Costa del Sol as an unsustainable tourism destination. 
Table 6: T-Test Of Difference Of Means Between The Expectations And Perceptions Of The Tourists Visiting The Western Costa Del Sol (Tourists Who Regard The Destination As SUSTAINABLE)

\begin{tabular}{|l|c|c|c|c|c|}
\hline & $\begin{array}{c}\text { Expectations } \\
\text { (Mean Value) }\end{array}$ & $\begin{array}{c}\text { Perceptions } \\
\text { (Mean Value) }\end{array}$ & $\begin{array}{c}\text { Difference } \\
\text { EXP-PER }\end{array}$ & t-test & $\begin{array}{c}\text { Signif. } \\
\text { (Bilateral) }\end{array}$ \\
\hline $\begin{array}{l}\text { Quality of the urban environment (cleanliness, } \\
\text { traffic, noise, etc.) (VI) }\end{array}$ & 5.0418 & 5.1934 & $-0.1516(+)$ & $-2.7183(*)$ & 0.0067 \\
\hline $\begin{array}{l}\text { Accessibility (communication network. } \\
\text { Access, ect.) (VI) }\end{array}$ & 5.0070 & 5.0714 & -0.0645 & -0.9513 & 0.3416 \\
\hline Quality of the natural environment (VD) & 5.0105 & 4.9878 & 0.0026 & 0.3933 & 0.6942 \\
\hline $\begin{array}{l}\text { Availability of local products and services } \\
\text { (VD) }\end{array}$ & 5.1725 & 5.2753 & -0.1028 & -1.8382 & 0.0663 \\
\hline Availability of a cultural programme (VI) & 4.2997 & 4.2561 & 0.0436 & 0.7187 & 0.4725 \\
\hline Customer service and care (VD) & 5.3345 & 5.5279 & $-0.1934(+)$ & $-3.0332(*)$ & 0.0025 \\
\hline Public safety (VI) & 5.4233 & 5.6150 & $-0.1916(+)$ & $-2.9310(*)$ & 0.0034 \\
\hline It is not an overcrowded destination (VD) & 4.4826 & 4.4390 & 0.0436 & 0.6478 & 0.5172 \\
\hline $\begin{array}{l}\text { Good relationship and attitude of residents } \\
\text { towards tourism (VI) }\end{array}$ & 5.1167 & 5.3397 & $-0.2230(+)$ & $-3.3425(*)$ & 0.0009 \\
\hline Availability of an urban transport system (VD) & 4.9443 & 4.8955 & 0.0488 & 0.8367 & 0.4029 \\
\hline $\begin{array}{l}\text { Good value for money (VD) } \\
\text { (VI): } t \text {-test of difference of means with equal sample variances (homoscedasticity). } \\
\text { (VD): } t \text {-test of difference of means with unequal sample variances (heteroscedasticity). }\end{array}$ & & $0.4338(-)$ & $6.5538(*)$ & 0.0000 \\
\hline $\begin{array}{l}\text { (+) Perceptions significantly higher than expectations. } \\
\text { (-) Expectations significantly higher than perceptions. } \\
\text { (*) Difference statistically significant at 5\% significance level } \\
\text { Source: Authors' own elaboration }\end{array}$
\end{tabular}

By analysing Tables 6 and 7 as a whole, it is observed that tourists defining the Western Costa del Sol as a sustainable tourism destination go home feeling highly satisfied as far as quality of the urban environment, attention and care, public safety, and good relationship and attitude of residents to tourism are concerned. Regarding these four aspects, it has been empirically verified that the experience of tourists has exceeded their expectations. Conversely, in the group of tourists who believe that the Western Costa del Sol is not a sustainable destination, perceptions exceed prior expectations only in the case of good relationship and attitude of residents to tourism. This particular aspect has also been observed in the first group of tourists. Therefore, it can be concluded that the friendliness and hospitality of the people living in the Western Costa del Sol have pleasantly surprised tourists visiting this destination. This attribute has generated a complex image, significantly better than the induced image that tourists had before travelling to the Western Costa del Sol. However, it does not allow for establishing differences between tourists (those who consider it as a sustainable destination or those who do not consider it as such).

This is not the case, however, with other aspects analysed. Therefore, it can be said that the perception of the tourism sustainability of the Western Costa del Sol has been based mainly on three main aspects:

- the high quality of its urban environment

- $\quad$ the good service and treatment that tourists visiting the destination receive

- $\quad$ the high degree of public safety that tourists perceive 
Table 7: $T$-Test Of Difference Of Means Between The Expectations And Perceptions Of The Tourists Visiting The Western Costa Del Sol (Tourists Who Regard The Destination As UNSUSTAINABLE)

\begin{tabular}{|l|c|c|c|c|c|}
\hline & $\begin{array}{c}\text { Expectations } \\
\text { (Mean Value) }\end{array}$ & $\begin{array}{c}\text { Perceptions } \\
\text { (Mean Value) }\end{array}$ & $\begin{array}{c}\text { Difference } \\
\text { EXP-PER }\end{array}$ & $\begin{array}{c}\text { Signif. } \\
\text { t-test }\end{array}$ \\
\hline $\begin{array}{l}\text { Quality of the urban environment (cleanliness, } \\
\text { traffic, noise, etc.) (VI) }\end{array}$ & 4.7090 & 4.7336 & -0.0246 & -0.2440 & 0.8073 \\
\hline $\begin{array}{l}\text { Accessibility (communication network. } \\
\text { Access, ect.) (VI) }\end{array}$ & 4.5451 & 4.6434 & -0.0984 & -0.8423 & 0.4000 \\
\hline Quality of the natural environment (VI) & 4.5656 & 4.0164 & $0.5492(-)$ & $5.3452(*)$ & 0.0000 \\
\hline Availability of local products and services (VI) & 4.7500 & 4.6270 & 0.1230 & 1.3044 & 0.1927 \\
\hline Availability of a cultural programme (VI) & 3.9467 & 3.8361 & 0.1107 & 1.0274 & 0.3047 \\
\hline Customer service and care (VI) & 4.7336 & 4.7828 & -0.0492 & -0.4301 & 0.6673 \\
\hline Public safety (VI) & 4.6598 & 4.7336 & -0.0738 & -0.6422 & 0.5211 \\
\hline It is not an overcrowded destination (VD) & 3.9631 & 3.8607 & 0.1025 & 0.8723 & 0.3834 \\
\hline $\begin{array}{l}\text { Good relationship and attitude of residents } \\
\text { towards tourism (VI) }\end{array}$ & 4.4918 & 4.7746 & $-0.2828(+)$ & $-2.4111(*)$ & 0.0163 \\
\hline Availability of an urban transport system (VI) & 4.6598 & 4.6189 & 0.0410 & 0.4301 & 0.6673 \\
\hline Good value for money (VD) & 4.8074 & 4.0041 & $0.8033(-)$ & $6.6354(*)$ & 0.0000 \\
\hline $\begin{array}{l}\text { (VI): } t \text {-test of difference of means with equal sample variances (homoscedasticity). } \\
\text { (VD): } t \text {-test of difference of means with unequal sample variances (heteroscedasticity). }\end{array}$ & & \\
\hline
\end{tabular}

(+)Perceptions significantly higher than expectations.

(-) Expectations significantly higher than perceptions.

(*) Difference statistically significant at $5 \%$ significance level

Source: Authors' own elaboration

Finally, two issues that should be subject to debate by the tourism stakeholders of Western Costa del Sol must be highlighted - good value for money and quality of the natural environment. The expectations that tourists had brought regarding these two issues have been ruined after the tourism experience. This has resulted in tourists having a poorer perception of the destination Western Costa del Sol as compared to that derived from their induced image. The first issue (good value for money) has been observed in those tourists considering this destination sustainable as well as in those perceiving it as unsustainable, both groups with a statistically significant positive difference between the mean value of expectations and the mean value of perceptions. By contrast, the second issue (quality of the natural environment), which should lead to reflection when looking for a sustainable tourism destination, is exclusive of tourists who believe that the Western Costa del Sol is nowadays not a sustainable tourism destination. Therefore, it seems quite clear that the perception of a destination as unsustainable is based predominantly on a negative assessment of the environmental quality of the natural environment of the Western Costa del Sol.

\section{CONCLUSIONS}

The results obtained have allowed the validation of the hypothesis set at the beginning of this research. There is, indeed, a different assessment of the tourism attributes of the destination analysed (the Western Costa del Sol) according to the perception of the tourists who visit it. This assessment will depend on whether they consider that they are visiting a sustainable destination or, on the contrary, that there are problems of unsustainability at the destination.

The survey that has been carried out is the first to analyse the phenomenon of sustainable tourism in the Western Costa del Sol from a demand perspective. The results show that the hospitality of the local population, the high level of public safety, the environmental quality of the cities of the Western Costa del Sol, and the improvement of the environmental quality of the natural environment of this destination constitute the pillars on which any strategy, public or private, seeking a greater comprehensive sustainability of the Western Costa del Sol should be based.

All studies and reports conducted have shown that the Western Costa del Sol is an unsustainable destination. That is also perceived to be so by the entrepreneurs, as well as policymakers and managers of the destination who initiated an ambitious restructuring program. However, it is striking that a good part (70.17\%) of the 
tourists who enjoy their holidays there consider it sustainable. This confirms the serious lack of awareness by tourists currently visiting this destination of what sustainability means and involves.

Tourists describing this destination as unsustainable show perceptions lower than expectations in six of the eleven attributes analysed. In four of the five attributes in which their perceptions exceeded their expectations, the difference in value has been minimal. By contrast, tourists who describe the destination as sustainable have shown perception values higher than the mean value of their expectations in six attributes (presenting higher differences between perceptions and expectations than those in the previous group).

In short, tourists considering that this destination is sustainable have higher expectations, so they are more difficult to satisfy. When their actual perception is lower than their expectations, this difference is very low (except for good value for money). However, when their actual perception exceeds their expectations, this difference is higher than in the previous case (there are four out of the eleven items analysed in which perceptions show a statically significant difference compared to expectations). Conversely, tourists considering that the destination is not sustainable show lower expectations than the previous group and their perceptions do not differ significantly from those expectations, since only a couple of attributes exist in which their dissatisfaction is noteworthy - good value for money and quality of the natural environment.

Therefore, an important question arises: "Is it possible to progress in sustainability of the destinations if tourists visiting them do not behave sustainably?" The answer seems to be clear. For a destination to advance in sustainability, it is not only enough to implement supply policies, but it is also necessary that "their" tourists are also involved in this process; that is, they must value (both ethically and economically) these issues. As Mazilu (2012: 96) states that raising awareness with regard to sustainability and ethics can facilitate the emergence of tourists' individual responsible attitudes and practices. Therefore, demand policies should be also implemented.

Finally, the authors should admit that a limitation of this research could be the fact that not all tourists surveyed had spent the same amount of time at the destination and, therefore, their perception may be different. It is possible that especially for those tourists who spent less time than others at the destination when they were surveyed were still unaware of some of the aspects included in the study. However, 50.98\% of tourists already spent more than three days at the destination when surveyed and $78.73 \%$ spent a minimum of two days, which seems to be enough time to have a strong opinion about most of the issues they were asked about.

\section{AUTHOR INFORMATION}

Juan Ignacio Pulido-Fernández is director of Laboratory of Analysis and Innovation in Tourism (LAInnTUR) at the University of Jaén. He obtained a Ph.D. in Economics at the University of Jaén and he is an Associate Professor in the Department of Economics. His academic background focuses on sustainability of tourism, destination management and economic development, tourism impacts, and social networks analysis in tourism. Juan Ignacio has published a number of articles in international peer-reviewed journals and several books and book chapters. He has served as main researcher in several national and international research projects and currently chairs the Spanish Association of Scientific Experts in Tourism (AECIT).

Yaiza López-Sánchez is a researcher at the University of Jaén. She is currently completing her doctoral thesis based on the willingness to pay for tourist destinations that are more sustainable. Her main research interests focus on sustainability of tourism, destination management, and economic development. She has published articles in international peer-reviewed journals and book chapters and has served as main researcher in several national and international research projects.

\section{REFERENCES}

1. Adlwarth, W. (2010). Corporate social responsibility: customer expectations and behaviour in the tourism sector, in R. Conrady, M. Buck (Eds.), Trends and Issues in Global Tourism. New York, NY: Springer, pp. 101-103.

2. Agarwal, S. and Shaw, G. (2007). Managing coastal tourism resorts. A global perspective. Clevedon: 
Channel View.

3. Alcaniz, E. B., Garcia, I. S. and Blas, S. S. (2005). Relationships among residents' image, evaluation of the stay and post-purchase behavior. Journal of Vacation Marketing, 11(4) 291-302.

4. Anuar, A. N. A., Ahmad, H., Jusoh, H., and Hussain, M. Y. (2012). Understanding the factors influencing formation of tourist friendly destination concept. Journal of Management and Sustainability, 2(1) 106-114.

5. Baloglu, S. and Brinberg, D. (1997). Affective images of tourism destinations. Journal of Travel Research, 35(4) 11-15.

6. Bigné, J. E., Sánchez. M. I., and Sánchez, J. (2001). Tourism image, evaluation variables and after purchase behaviour: inter-realationship. Tourism Management, 22 607-616.

7. Bramwell, B. (2004). Mass Tourism, Diversification and Sustainability Development in Southern Europe's Coastal Regions, in Bramwell, B. (ed.), Coastal Mass Tourism. Diversification and Sustainable Development in Southern Europe. Clevedon: Channel View Publications, 1-31.

8. Chen, C. F. and Tsai, D. (2007). How destination image and evaluative factors affect behavioral intentions? Tourism Management, 28(4) 1115-1122.

9. Chon, K. S. (1990). The role of destination image of tourism: a review and discussion. The tourism review, $452-9$.

10. Chon, K. S. (1992). Self-image/destination image congruity. Annals of Tourism Research, 19(2) 360-363.

11. Cooper, C., Fletcher, J., Gilbert, D., and Wanhill, S. (1993). Tourism: Principles and practice. London: Pitman Publishing.

12. Crompton, J. (1979). An assessment of the image of Mexico as a vacation destination and the influence of geographical location upon the image. Journal of Travel Research, 17(4) 18-23.

13. Deloitte. (2008). The staying power of sustainability: Balancing opportunity and risk in the hospitality industry. Deloitte Development.

14. Dodds, R., Graci, S. R., and Holmes, M. (2010). Does the tourist care? A comparison of tourists in Koh Phi Phi, Thailand and Gili Trawangan, Indonesia. Journal of Sustainable Tourism 18(2) 207-222.

15. Echtner, C. M. and Ritchie, J. R. B. (1991). The meaning and measurement of destination image. The journal of tourism studies, 2(2) 2-12.

16. Fakeye, P. and Crompton, J. (1991). Image differences between prospective, first-time, and repeat visitors to the lower Rio Grande valley. Journal of Travel Research, 30(2) 10-16.

17. Folgado, J. A., Oliveira, P. A., and Hernández, J. M. (2012). Brand image and tourist destination: synergies and implications. Tourism \& Management Studies, 1 904-914.

18. Galacho, F. B. (2009). Reflexiones acerca del modelo territorial desarrollado por el planeamiento urbanístico en los años noventa del siglo XX en la Costa del Sol. Estudios de Arte, Geografía e Historia 31 35-59.

19. Gómez, M., García, J. A., and Molina, A. (2012). Imagen cognitiva de los destinos de interior desde la perspectiva de residentes y visitantes: una aplicación empírica en 4 regiones españolas. Cuadernos de Economía y Dirección de la Empresa. Doi: http://www.sciencedirect.com/science/article/pii/S1138575812000795.

20. Gopalan, R. and Narayan, B. (2010). Improving customer experience in tourism: A framework for stakeholder collaboration. Socio-Economic Planning Sciences, 44(2) 100-112.

21. Hedlund, T. (2011). The impact of values, environmental concern, and willingness to accept economic sacrifices to protect the environment on tourists' intentions to buy ecologically sustainable tourism alternatives. Tourism and Hospitality Research, 11(4) 278-288.

22. Henderson, J. C. (2007). Uniquely Singapore? A case study in destination branding. Journal of Vacation Marketing, 13(3) 261-274.

23. Hunt, J. D. (1975). Image as a factor in tourism development. Journal of Travel Research, 13(1) 1-7.

24. Kim, H. and Richardson, S. L. (2003). Motion picture impacts on destination images. Annals of Tourism Research, 30(1) 216-237.

25. Kotler, P., Haider, D. H., and Rein, Y. (1993). Marketing places: attracting investment, industry and tourism to cities, states and nations. New York: The free Press.

26. Kucukusta, D., Mak, A., and Chan, X. (2013). Corporate social responsibility practices in four and five-star hotels: Perspectives from Hong Kong visitors. International Journal of Hospitality Management, 34 19-30.

27. Lonely Planet. (2007). Lonely Planet survey reveals travelers seek sustainable options.

28. Mazilu, M. (2012). Sustainable Tourism of Destination, Imperative Triangle Among: Competitiveness, 
Effective Management and Proper Financing. Sustainable Development-Policy and Urban DevelopmentTourism, Life Science, Management and Environment. IntechOpen.

29. Miller, G., Rathouse, K., Scarles, C., Holmes, K., and Tribe, J. (2010). Public Understanding of Sustainable Tourism. Annals of Tourism Research, 37(3) 627-645.

30. Morgan, N., Pritchard, A., and Pride, R. (2012). Destination Brands. Routledge.

31. Murphy, L., Benckendorff, P., and Moscardo, G. (2007). Linking travel motivation. Tourist selfimage and destination brand personality. Journal of travel and tourism marketing, 22 45-49.

32. Navarro, E. (2005). ¿Puede seguir creciendo la Costa del Sol? Indicadores de saturación de un destino turístico. Málaga: CEDMA.

33. Navarro, E. (2006). Proceso de crecimiento e intensificación de usos en los destinos turísticos consolidados, en Turismo y cambio territorial: ¿eclosión, aceleración, desbordamiento?, Lacosta Aragüés, A. Actas del VIII Coloquio de Geografía del Turismo, Ocio y Recreación, Zaragoza, Prensas Universitarias de Zaragoza, 319-350.

34. Navarro, E. (2010). La Costa del Sol Occidental y el Plan Qualifica: nuevos modelos para la gestión de destinos y ¿procesos de renovación?”, Taller de trabajo sobre renovación de los destinos turísticos consolidados del litoral. Instituto Universitario de Investigaciones Turística, Universidad de Alicante. Retrieved from: http://blogs.ua.es/renovestur/panel-de-expertos/ (Accessed: January 15, 2013).

35. Pulido, J. I. and López, Y. (2013): "Regeneration of mature coastal tourism destinations: Three case studies in Spain", en Mihalič, T. \& Gartner, W.C. (eds.): Tourism and Developments - Issues and Challenges, Nova Science Publishers, Inc., New York, 303-334.

36. Qu, H., Kim, L. H., and Im, H. H. (2011). A model of destination branding: Integrating the concepts of the branding and destination image. Tourism Management, 32(3) 465-476.

37. Sahli, M. and Nowak, J. J. (2007). Does inbound tourism benefit developing countries? A trade theoretic approach. Journal of Travel Research, 45(4) 426-434.

38. Rheem, C. (2009). PhoCusWright's Going Green: The Business Impact of Environmental Awareness on Travel. PhoCusWright Inc, Sherman (USA). Retrieved from: http://travelgreen.org/files/PhocusWright.pdf (Accessed: 5 September 2012).

39. San Martín, H. (2005). Estudio de la imagen de destino turístico y el proceso global de satisfacción: adopción de un enfoque integrador. Universidad de Cantabria.

40. San Martin, H. and Rodríguez del Bosque, I. A. (2008). Exploring the cognitive-affective nature of destination image and the role of psychological factors in its formation. Tourism Management, 29(2), 263277.

41. Sánchez, M. and Pulido, J. I. (2012): “Testing heterogeneous image in cultural/non cultural tourism markets: A latent model approach”. International Journal of Tourism Research, 14(3) 250-268.

42. Szymanski, D. and Henard, D. (2001). Customer satisfaction: a meta-analysis of the empirical evidence. Journal of the Academy of Marketing Science, 291635.

43. Vera, J. F. and Rodríguez, I. (2010). Tourism strategies for the renovation of mature coastal destinations in Spain, in IV International Conference on Sustainable Tourism, New Forest, United Kingdom.

44. Wehrli, R., Egli, H., Lutzenberger, D., Pfister, J., Scwarz, J., and Steettler, J. (2011). "Is there demand for sustainable tourism?" Study for the World Tourism Forum Lucerne 2011, ITW. Working Papers Series Tourism 001/2011. Lucerne University of Applied Sciences and Arts. 